\title{
A PNEUMA SZÖV. CSOPORT UTCASZÍNHÁZA ÉSA RÉSZVÉTEL HÁROM DIMENZIÓJA
}

\author{
Bálint Mónika \\ monika.balint@gmail.com
}

D O I : $10.20520 /$ J E L - K EP. 2017.1 .47

\begin{abstract}
Absztrakt
A tanulmány a Pneuma Szöv. müvészcsoport és a Mobile Albania német performansz-csoport közösségi müvészeti tevékenységét mutatja be a 20 forintos operett projektből ${ }^{1}$ kiindulva, a szerző saját megfigyeléseire, a projektről megjelent cikkekre és a programot kezdeményező interjúkra építve. Utcai akcióival, utcaszínházi előadásaival, köztéri vetítéseivel a csoport az utca közösségeinek és a hajléktalanságnak, a szegénységnek, a társadalmi kirekesztettségnek a kérdéseit dolgozza fel szoros együttmüködésben az érintettekkel, Budapest VIII. kerületének szegénységben élő lakóival és hajléktalanjaival. Az írás a projekt elemzésén keresztül bemutatja a részvételi alapú műalkotásokban és a társadalomtudományi diskurzusban megjelenő részvétel-fogalom háromféle értelmezési lehetőségét - a részvétel három dimenzióját.
\end{abstract}

\section{Kulcsszavak}

utcaszínház, társadalmilag elkötelezett művészet, részvétel, a részvétel dimenziói

\section{THE 20 FORINT OPERETTA - THREE DIMEN - SIONS OF PART ICIPATION}

\section{Món i k a Bálint}

\section{Abstract}

The 20 Forint Operetta (inspired by Bertolt Brecht's and Kurt Weill's Dreigroschenoper) is a joint project of the Hungarian Pneuma Szöv. artist group and the German performance group Mobile Albania, in which a common space, a living open society of trust and cooperation is being created by artists, activists, ,street experts" and inhabitants of Budapest. ${ }^{2}$ The paper presents an analysis of this long term art project based on participatory observations, articles, and interviews with the initiators of the project. The analysis of the 20 Forint Operetta discusses three possible interpretations of participation as it relates to participatory artwork - the three dimensions of participation.

\section{Keywords}

street performance, socially engaged art, participation, dimensions of participation

\footnotetext{
${ }^{1}$ A projekt dokumentációja elérhető a csoport honlapján: http://www.pneumaszov.org/magyar/projects.html

${ }^{2}$ http://www.pneumaszov.org/current.html; https://www.facebook.com/20ForintosOperett?fref=ts
} 


\title{
A PNEUMA SZÖV. CSOPORT UTCASZÍNHÁZA ÉSA RÉSZVÉTEL HÁROM DIMENZIÓJA
}

\author{
Bálint Mónika
}

A Pneuma Szöv. müvészcsoport 2008 óta, gyakran a német Mobile Albania alkotócsoporttal együttmüködésben hoz létre közösségi, társadalmilag elkötelezett, részvételi alapú mủvészeti projekteket, melyek jelentős része köztéren jön létre. Az alkotás folyamatába direkt módon meghívást kapnak a köztéren és egy adott lakókörnyezetben élők, indirekt módon pedig a járókelők, akik a csoport eseményeivel, installációival találkoznak. A színház, a képzőművészet és a médiamüvészet eszközeit vegyítve hoznak létre a „hálózattá” növekedett csoport alkotói olyan alkotásokat, amelyek társadalmi igazságtalanságokat tárnak fel kreatívan és soksok humorral. A hálózat magját Sarah Günther és Berecz Zsuzsa színházi rendezők, valamint Szabados Luca képzőmüvész alkotják, változó, több tucatnyi rendszeres alkotótárssal és több száz alkalmi alkotóval együttmüködve.

Az alábbi elemzés elsősorban a 2012-ben elindult 20 forintos operett címü utcai projektsorozat első állomásait mutatja be, melyek helyszíne Budapest nyolcadik kerülete, témája pedig a társadalmi kirekesztés és a hajléktalanság. „A budapesti Pneuma Szöv. hálózat és a német Mobile Albania színházi kollektíva projektjének kiindulópontja a köztér, ahol az aktuális társadalmi-politikai átalakulások lecsapódnak, zajlanak, és ahol közös terek nyílhatnak meg a változások számára. A 20 forintos operett címe Bertolt Brecht és Kurt Weill Koldusoperájára utal, hiszen Budapest utcái a számtalan hajléktalannal és az öket övező rendőri és állam(polgár)i szigorral Peachum koldus államára emlékeztetnek. A 20 forintos színház célja, hogy a monetáris peremvidékek müvészeit a középosztály számára fenntartott terekbe, zónákba hívja, hangjukat hallhatóvá tegye, és a közös alkotási folyamaton keresztül megtapasztalhatóvá, kézzelfoghatóvá formálja egy új, nyitott társadalom lehetőségét. A eldobott gondolatok, tárgyak és helyek tömegesen újratermelődő hulladékaiból épül fel a 20 forintos operett szegény színháza. A projekttel ideológiákon és a társadalmi polarizáción túlmutatóan olyan közeget és közösséget keresünk, amelyben élni szeretnénk. A bizalmatlansággal bizalmat helyezünk szembe, a szabályokkal a játékot és az alkotás örömét. A müvészet számunkra nem eszköz egy cél elérésére, hanem az a terep, ahol valami új jöhet létre" - írják az alkotók a projekt honlapján.

\section{Az utca}

A Tolnai Lajos utca Budapest nyolcadik kerületének egy jellegzetesen sokoldalú utcája. A József utcai szobrászmühelyeket köti össze a Népszínház utcát övező egykori kiskereskedő és vigalmi negyeddel, de leghírhedtebb intézményei már vagy egy évszázada a bünözéshez kötődnek. A XX. század elején a vigalmi negyed részeként az akkori Conti utcában bordély- 
házak, kocsmák, mulatók voltak. Ebben az utcában, egy üres telken, a helyi óvoda használaton kívüli játszóudvarán egy közösségi színházi alkotás és egy mobil, multifunkcionális mókusszobor született 2012 nyarán.

„A 20 forintos operett Bertolt Brecht és Kurt Weill Koldusoperájából kiindulva az utca mint közös tér lehetőségeivel foglalkozik, és az operett müfaját az utca terébe helyezve egy aktuális utcafantáziát hoz létre" - írja Sara Günther, Berecz Zsuzsa és Szabados Luca a Képzöés Iparmúvészeti Lektorátusnak beadott pályázati koncepcióban. A kerület jelenleg is tökéletes terepet ad a Koldusopera mondanivalóinak felelevenítésére, de valószínüleg ez még inkább így volt Brecht idejében. Az operettben az utcából tenger lesz, együtt kel át a Nyolcadik Tengeren a Mókushajó segítségével minden résztvevő, minden állat és minden tengerész.

\section{Mókus Maxi születése}

A 20 forintos operett ötlete akkor született meg Sara Günther fejében, amikor a Hajléktalan Mủvészek Fesztiválján találkozott Horváth Csilla, alias HoCsi, Mókus Márkus címü novellájával. A történet főszereplője Mókus Márkus, aki átoperáltatja magát, hogy emberszerű ruhát öltve és emberi hangon beszélve képviselhesse az állatok érdekeit az Állati Jogok Országgyülési Biztosaként. „Az első panasz, amit Mókus Márkus asztalára tettek, a Pilisi Parkerdőből érkezett. Ugyanis az Erdei Önkormányzat Vadkan Valér polgármester és Róka Rudolf ellenzéki alpolgármester közös javaslatára helyi rendeletben kitiltotta az erdőből a meztelen csigákat, közszemérmet sértő magatartásukra hivatkozva. A panaszt a meztelen csigák jogi képviselöje nyújtotta be, és nem titkolta azon véleményét, miszerint azért üldözik öket, mert gyakorlatilag hajléktalanok."3

A HoCsi-féle társadalmi szatíra folytatása lett Mókus Maxi, az unoka története, amit egy közösségi müalkotásként születő operettben énekeltek meg magyar és német müvészek, Józsefváros különböző lakói, hajlékkal rendelkezők és hajléktalanok. Kéthónapos nyitott mühelymunka során épült fel a gigantikus „mókusmobil”, amely hangszer és gyümölcsfacsaró gép egyben, és egy ember számára még lakóhellyé is válhat. A közös munkának viszonylag szigorú kereteket adott a müvészek által tervezett forgatókönyv megvalósítása: a cél, hogy két hónap alatt elkészüljön a mókus és az operett. Mindemellett mégis maradt rengeteg idő és tér ahhoz, hogy bárki bekapcsolódhasson, amivel szeretne, és amivel tud. Ez sokaknak megadta azt a szabadságérzetet, ami a kreatív alkotói tevékenység fontos üzemanyaga. „A projekttel nyitott közösséget szerettünk volna létrehozni, egy nyitott társadalmat kicsiben, ahol a legkülönbözőbb háttérrel rendelkező lakók és müvészek találkozhatnak egymással egy közös alkotófolyamaton keresztül, és ahol a szegények és hajléktalanok hangja is hallhatóvá válik."4

A Tolnai Lajos utca 23. egy fiktív országon belüli országgá vált napokon belül, a saját közösségével, szabályaival, szokásrendszerével, kis füszer- és zöldségeskerttel, sőt még saját gazdasága is lett. A mókus építésébe és a projekt egészébe egy sajátos gazdasági eszköz is segített bekapcsolódni: a mókus teste speciális műanyag palackokból épült, amelyeket a telken lehetett beváltani. Mindenki, aki ilyen palackokat hozott be, kapott 10 forintot és 10 mókusforintot - helyi pénzt. A pókerzsetonokból készült mókusforintot a telken lehetett elkölteni szolgáltatásokra vagy a csere-bere piacon bármilyen tárgyra. Találóan olyan típusú palackokat vártak a mókus építői, amelyekbe jellemzően az olcsó borokat, italokat csomagolják, és amelyeket a szegényebb emberek, jellemzően a hajléktalanok vásárolnak. Volt, aki csak a palackokat hozta, megkapta a pénzt, körbenézett és elment, de mások visszajáró tagjaivá váltak az alkotóközösségnek.

${ }^{3}$ HoCsi: Mókus Márkus. Fedél Nélkül, 2008.augusztus, 367. szám.

${ }^{4}$ Blog bejegyzéss: szeptember 9., http://www.facebook.com/20ForintosOperett. 
Mókus Maxi története talán legjobban az építéssel és az operett előkészületeivel párhuzamosan forgatott, ötrészes 20 forintos szappanoperettben bontakozott ki, amelyet rengeteg improvizációra, a résztvevők ötleteire építve forgattak a projekt közel két hónapja alatt. A szappanoperett története a következő: Mókus Maxi a városban él a Tolnai Lajos utca 23. alatti telken, ahol a homokozó közepén sós víz tör fel (az operettben ez lesz a nyolcadik tenger forrása). A különleges jelenségre felfigyel Wellness Jenő és családja, és kenőpénzzel megszerzik a telket az önkormányzattól. Wellness elüzi Maxit, hogy szállót építhessen a sós forrás fölé. Közben Maxi beleszeret Bíborkába, Wellness Jenő lányába, amiért annak apja haragra gerjed, és elküldi a lányt Münchenbe. De egy napon Jenő azt látja, hogy a sok-sok pénze papírfecnivé válik, a valóság összekuszálódik. Jenő megzavarodik, majd a következő nap ébredése után kiderül, a „valóságban” Maxi élete csak mese, öt pedig nem Jenőnek, hanem Gyurinak hívják, nem gazdag, és a 20 forintos operett egyik résztvevője.

\section{Brecht: Die Dreigroschenoper}

A Koldusopera nem hősökről szól. Nincs olyan szereplője, akivel a néző szívesen azonosulna - Brechtnek nem is ez volt a célja -, ugyanakkor minden szereplö sorsában felfedezhet olyan helyzeteket, történéseket, problémákat, amikkel már találkozott az életében. Minél szegényebb valaki, annál könnyebb megtalálni ezt a közös emléket. A nyolcadik kerületi Józsefváros lakóinak életét is ezer ilyen szál köti a koldusopera alakjaihoz. Szegények, akik hol kéregetésre, hol guberálásra vagy akár - ha morális korlátaik nem tartják vissza - lopásra kényszerülnek a túlélésért.

Claire Bishop a részvételi alapú művészeti alkotás egyik előfutárának tekinti Brechtet (Bishop 2006). Első hallásra ellentmondásosnak találhatjuk, hogy pont az elidegenítést (a Veffektust $=$ az elidegenítés brechti elméletének gyakorlati megvalósítására kidolgozott dramaturgiai és rendezési eljárást) hangsúlyozó színházi gondolkodót kapcsoljuk össze a közönség aktív bevonásával az alkotói folyamatba. Akkor válik mégis érthetővé Bishop érvelése, ha a részvételt nemcsak performatív, hanem mentális cselekvésként is értelmezzük, illetve akkor, ha a müben a társadalmi részvétel reprezentációját fedezzük fel. Brecht az elidegenítést az érzelmi bevonódás korlátjaként javasolja az elgondolkodtatás érdekében, aktív szellemi munkát, mentális bevonódást vár a nézőtől. A cél a társadalmi viszonyok megértése, újraértelmezése, Brecht - legalábbis munkássága egy jelentős szakaszában - a színház nevelő funkcióját hangsúlyozza, marxista, dialektikus és didaktikus színházat teremt. Tevékenységét ilyen értelemben mindenképpen tekinthetjük társadalmilag és politikailag is elkötelezettnek. , [A müvész] álláspontja, amit elfoglal, társadalomkritikai álláspont. A folyamatokat úgy állítja be és a figura jellemzésében azokat a vonásokat dolgozza ki, amelyek társadalmi vonatkozásúak. Játéka így (a társadalmi állapotokról szóló) disputává válik a közönséggel, amelyhez fordul. Ráveszi a nézőt, hogy - osztályhelyzete szerint - helyeselje vagy helytelenítse ezeket az álláspontokat." (Brecht 1969)

A részvételi alapú alkotás szempontjából ugyanakkor talán nem is annyira elméleti munkássága miatt fontos tanulmányozni Brechtet, hanem későbbi rendezői tevékenysége miatt. A kollektív alkotással kísérletezett, ezáltal pedig a közösségi színház gyakorlatát alapozta meg. Társulatának minden tagját egyenrangúnak tekintette, és nagy hangsúlyt helyezett a hosszú ideig tartó, közös alkotási folyamatra.

A 20 forintos operett egyes formai elemeiben, mint az utcai szituációk teremtése - nem a színpadon, hanem a valódi utcán - vagy a „songok” és látványos feliratok alkalmazása, épít a brechti színház főbb jellemzőire. De ennél is fontosabb a didaktikus jelleg, a polgári értékrend kritikája, illetve a polgári életmódból és értékrendből kirekesztődő társadalmi rétegek helyzetének bemutatása. 
A projekt több felületen - szintéren - létezett és létezik: a telek, az utcai performanszok, a szövegek, a dalok, a létrejött tárgyak, a fényképes és filmes dokumentációk, a szappanoperett, a blog és a projekt Facebook oldala mind egy folyamatalapú színházi alkotás elkülönülö elemei.

Sarah Günter szerint érdemes a projekt müfaját a legtágabb értelemben vett színháznak nevezni. És lehet, hogy igaza van, mert minden más müfaji kategorizáció talán a projekt olyan elemére helyezné a hangsúlyt, amely nem az összes résztvevő számára lényeges. Közösségi színház, public art projekt, utcaszínház, alkotómühely vagy (ahogy Orbán Anna nevezte) szociokulturális happening - ezek mind lehetséges olvasatai és müfaji megnevezései a 20 forintos operettnek; válassza mindenki azt, ami a szívének a legkedvesebb. A projekt megítélésének kulcsa kétségtelenül a résztvevők pozíciójától és motivációitól függ, és attól is, hogy a részvétel lehetséges dimenziói közül ki mire helyezi a hangsúlyt.

\section{A részvétel dimenziói}

Részvételi müvészetnek vagy részvételi alapú müvészeti projekteknek elsősorban azokat a müvészeti alkotói folyamatokat szokás tekinteni, amelyek egy adott társadalmi csoport vagy közösség aktív bevonására épülnek. Ugyanakkor, ha elfogadjuk Claire Bishop megközelítését, aki a részvétel elemét a müvészetben a mentális bevonódásig és a performativitásig vezeti vissza, a részvételt nem kell szigorúan az aktív jelenléthez és cselekvéshez kötni. Viszont ezzel túlságosan tág keretet kapunk és eljuthatunk egy olyan érvelésig is, amely minden müalkotást részvételi alapúnak enged bemutatni. Hasznos lehet a bishopi fogalmi keretet kicsit szükítve a részvétel különböző szintjeit, illetve színtereit megkülönböztetni, és elkülöníteni, hogy kinek a szempontjából beszélünk részvételről - utóbbiakat a részvétel dimenzióinak nevezem, és konceptualizációjuk során a társadalomtudományokban megjelenő részvétel-értelmezésekre támaszkodom. A projektek elemzése részben a müvész és az általa bevont résztvevők interakciójának elemzésére vonatkozik.

A következő dimenziókat különítem el:

1. A részvétel a müvész dimenziójában - a müvész mint résztvevő.

2. A részvétel a közönség, az alkotásba bevont személyek szempontjából - „részvételi alkotás".

3. A részvétel a társadalmi nyilvánosság szempontjából - a részvétel mint társadalompolitikai dimenzió.

\section{A részvétel a müvész dimenziójában - a müvész mint részt vevö}

A részvétel eme dimenziójában a müvész szerepe a társadalomtudományokban alkalmazott résztvevö megfigyelö szereppel állítható párhuzamba. Az ágens - a mü alkotását kezdeményező művész - ebben a pozícióban a passzív megfigyelői szereptől közelít egy aktív cselekvő szerep felé. A résztvevő megfigyelő szerep sajátossága az, hogy a kutató a kutatott társadalom, közösség, csoport megismerését úgy végzi, hogy részt vesz annak mindennapjaiban, tehát a másik sajátvilágát tárja fel, a másik sajátvilágába való belehelyezkedésre tesz kísérletet. Ebben a folyamatban mégis érvényesül egyfajta távolságtartás, a kutató sajátvilágába való betekintésre a másiknak kevés lehetősége van. Ami még ennél is fontosabb, hogy a problémák megfogalmazásában és a megoldás keresésében a „megfigyelteknek” csak az ,adatszolgáltatói” szerep jut. A XX. század második felében kialakult részvételi akciókutatás ebben a tekintetben hoz változást. A megfigyelő és a megfigyelt, az ,én” és a „másik” között csökken a távolság, és a megismerés folyamatában mindegyik szereplö részt vesz. (Vörös és Frida 2006)

A részvételi müvek egyik fö sajátossága az, hogy a képzőmüvészet hagyományos eszközeivel szemben itt a személyközi kommunikáció sajátosságai érvényesülnek. Erre a sajá- 
tosságra helyezi a hangsúlyt Claire Bishop, amikor a részvételi müalkotásokat a performansz és az akciómüvészet hagyományára vezeti vissza, és ez teremti meg a kapcsolatot a képzőművészet és a színház között a részvételi alkotások területén. A hagyományos performansz és akció esetében az alkotó közvetlen kapcsolatot keresve a közönséggel saját cselekvését és testét a mü részévé teszi, és a nézőket is cselekvésre, testük bevonására készteti. Ezekben a performatív helyzetekben az alkotó teste és cselekedetei médiummá válnak.

A müvész sajátvilágának feltárásáról a másik megismerésére kerül a hangsúly a közösségekben születő (helyspecifikus, közösségi, public art) müalkotások esetében. Minél nagyobb lehetősége van a bevontaknak a mü alakítására, annál több lehetőségük van a sajátviláguk egyes elemeinek feltárására. A müvész és a bevont résztvevők közötti kapcsolatfelvétel és interakció elemezhető az interakció során betöltött szerepek, illetve a résztvevők én-megjelenítései alapján. A müvész minden esetben tudatosan irányítja az interakciókat aszerint, hogy milyen cselekvésre kívánja késztetni a bevont ágenseket, és magát milyen módon kívánja megjeleníteni. Alapesetben a cél lehet maga az interakció létrejötte.

Bár Ervin Goffman interakció-elmélete (Goffman 2000) elsősorban a hétköznapi életben létrejövő személyközi kommunikáció helyzeteinek elemzésére szolgál, és célja szerint a munkahelyi és egyéb szervezetekben megmutatkozó interakciós mintázatok értelmezését kívánja segíteni, mégis egy nem hétköznapi interakciós típus és színtér, a színház fogalomrendszerére épít. A dramaturgiai modell a részvételi projektek interakcióinak, performatív szituációinak értelmezéséhez is hozzájárulhat. Az interakciót kezdeményező személy viselkedése azért speciális, mert miközben általában a saját én-megjelenítése és a partnerek (a másik) elvárásai szerint a müvész szereppel kapcsolatos társadalmi elvárásokat, mintákat teljesíti, gyakran lép át más szerepekbe. Ilyen szerepek lehetnek a tanár, a kutató, az újságíró vagy a segitö szerepek. A müvész részben tudatosan keveri ezeket a szerepeket, vagy tudatosan mutatkozik meg a művész szerep helyett más szerepben, hogy ezzel a partnerek cselekedeteit és az interakció kimenetelét befolyásolja.

Egy konkrét műalkotás, alkotói folyamat jellemzésekor a következő kérdések nyomán írhatjuk le a részvétel jellemzőit annak első dimenziójában: Mi a (müvész részéről) a kapcsolatteremtés célja? Mi az interakció célja? Milyen problémákat fogalmazhat meg az ágens? Milyen szerepbe helyezkedik a művész? Hogyan definiálja saját szerepét a résztvevők felé? Mik az én-megjelenítés eszközei? Miként percipiálják a résztvevők a müvész szerepét?

\section{A részvétel az alkotásba bevont személyek szempontjából}

Ebben a dimenzióban a részvétel fogalma az alkotásba bevont egyénekre vonatkozik, ezért a bevonás mértékét és módszereit érdemes vizsgálni. Sajnos ez az a dimenzió, ahol az elemzés lehetőségei a leginkább korlátozottak. Ahhoz, hogy a „bevont” ágenseknek a dimenzióját megismerjük és megfelelő tudást szerezhessünk velük kapcsolatban, a projektek dokumentációi nagyon kevés segítséggel szolgálnak. A dokumentációkból ugyanakkor következtetni tudunk arra, hogy milyen mértékben volt lehetöségük a bevont ágenseknek a közös cselekvés egyes elemeinek alakítására és hogy milyen lehetőségeik voltak az én-megjelenítésre, de egy nagyon erős szürőn keresztül: azon a szürőn keresztül, amit a mủvész a nézők számára biztosít. (Erről a szürőről a harmadik dimenzió bemutatásakor lesz majd szó.) A mü alkotásába bevont ágensek olyan interakcióba kerülnek, amelynek számos részletét a müvész határozza meg. A részvétel mértéke attól is függ, hogy ezeknek a tényezőknek a meghatározásában a bevont ágenseknek milyen választási vagy változtatási lehetőségük van.

A bevontak dimenziójával kapcsolatban érdemes vizsgálni, hogy milyen módon alakíthatják a szereplők a projekt (a mü) végkimenetelét. Sazanne Lacy (Lacy 1994) felhívta a figyelmet arra, hogy a médiamüvészetben népszerüvé vált interaktivitás fogalma nélkülözi a 
valódi kölcsönösséget, és a bevont ágensek számára csak választási lehetőségeket ad, ami viszont a bevonódásnak egy alacsonyabb szintjét jelenti. Az egyén ilyenkor csak kész forgatókönyvek közül választhat, vagyis az interakcióban megmutatkozó problémára a müvész által felkínált megoldások egyikét. Ezzel szemben az olyan műalkotásokban, amelyeket Grant H. Kester dialogikusnak nevez (Kester 2004), az ágensek között valódi párbeszéd alakul ki, amely kölcsönösséget és együttmüködést feltételez. Az interakció kimenetele ebben az esetben nem elöre meghatározott, nincsenek olyan zárt forgatókönyvek, amelyek közül választani lehetne. Kester elméletében Habermas kommunikatív cselekvés elméletére és a beszédaktuselméletre támaszkodik. A dialógusban Habermas elmélete szerint az ágensek (Habermas cselekvéselméletében az aktorok) szimmetrikus (hatalmi) viszonyban állnak. Ez az idealizált helyzet azonban nehezen teljesül egy müvészeti projektben, de az ágensek törekedhetnek rá. Az interakció során a dialógusban szereplő ágenseknek két veszélyforrást kell elkerülniük. Ezek a meghiúsult kölcsönös megértés (egyet-nem-értés vagy félreértés) és a meghiúsult cselekvésterv (sikertelenség) kockázata (Habermas 1986: 188). A gyakorlatban azonban ezek a veszélyforrások nem jelentenek egyenlő mértékben fenyegetést minden ágens számára. A müvészeti projektek esetében feltételezhető, hogy megfelelő szintű bevonódás és elkötelezettség hiányában az alkotásba bevont ágensek számára sem a félreértés lehetösége, sem a cselekvés sikertelensége nem olyan fenyegető, mint a tervei megvalósításában érdekelt müvész számára.

A második dimenzióval kapcsolatban megfogalmazható kutatói kérdések: Mik a bevonás eszközei? (Milyen környezetben és helyzetben valósul meg az interakció?) Milyen szinten valósul meg a bevonódás, milyen cselekedetekre terjed ki? Hogyan definiálja a müvész a résztvevőket szerepük és identitásuk szerint? Milyen szerepben mutatkoznak meg az ágensek? Létre jön-e koalíció a résztvevők között? Milyen lehetőségük van a bevontaknak arra, hogy alakítsák én-reprezentációjukat, szerepeiket, és bemutassák identitásukat? Milyen szerepben mutatkoznak meg? Milyen az ágensek viszonya a problémák identifikálása és eliminálása kapcsán? Amennyiben a müvész az interakció által a müalkotásba beépíthető ismereteket kíván szerezni, mennyire nyitott ez a folyamat, milyen előfeltevésekből indul ki és mennyire épít a partnerek sajátvilágára? Milyen témákat jelenítenek meg a bevont ágensek (sajátviláguk mely szeleteit tárják fel)?

\section{A részvétel a társadalmi nyilvánosság szempontjából}

A folyamatalapú és performatív részvételi müvészeti projektek esetében a mü a szélesebb nyilvánosság számára, a müvészeti mezőben általában az interakció dokumentációja révén kerül bemutatásra, fényképeken, videofelvételeken, visszaemlékezéseken keresztül. Az interakcióknak a reprezentációit ismerheti meg a közönség (amennyiben a mübe bevont ágenseket is közönségként percipiáljuk, őket tekintetjük a mü elsődleges közönségének, a mű dokumentációját szemlélőket pedig a másodlagos közönségnek). A dokumentáció az eredeti interakciónak csak azon elemeit tartalmazza, amelyeket a szerkesztés során a müvész kiválasztott. A művész sajátvilágának elemei válnak elérhetővé, a többi ágensé csak az ő szemének és tudatának szürőjén keresztül. Ami megismerhető: Milyen általános ismereteink lehetnek a müvek közönségéről? Kikhez szólnak ezek a munkák? Ha magunkat tekintjük nézőnek, be tudunk számolni arról, hogy milyen ,üzeneteket” tartalmaz felénk a mü, a valóság milyen szeleteire vonatkozik, illetve annak milyen képe születik a sajátvilágunkban, esetleg milyen cselekvéseket vált ki belölünk (az aktor perspektívája)?

Általánosságban elmondható, hogy Magyarországon a képzőmüvészeti mezőben egy állandó és nehezen leküzdhető ellentmondás mutatkozik meg a müvek nyilvánosságával kapcsolatban. Míg a társadalmilag és/vagy politikailag elkötelezett müvekkel kapcsolatban az alkotók egy része és a kritikusok egy része is azt az elvárást fogalmazza meg, hogy azok hatást gyakoroljanak a bennük reprezentált társadalmi kérdésekre (viszonyokra, problémákra), 
a művészeti nyilvánosság, vagyis a galériákba járó közönség által alkotott nyilvánosság korlátozott, szük. A másik probléma a közönség attitüdje: sok esetben olyan nézök ismerkednek meg ezekkel a müvekkel, akik maguk is hasonló társadalmi, politikai elkötelezettséget mutatnak. A rétegnyilvánosság ilyen jellegü korlátozó jellegét hivatottak leküzdeni például a public art alkotások, amelyek a galériák falain kívül található közönségnek szólnak.

A részvétel politikai fogalma annyiban áll közel a részvétel eme dimenziójához, amenynyiben lehetségesnek tartjuk, hogy az alkotás összekapcsolja a bevont ágenseket (egyéneket, csoportokat) és a társadalmi nyilvánosságot (az ágens fogalmáról a kommunikáció participációra alapozott felfogása szerint lásd: Horányi 2005, 2007). A néző számára bizonyos ismeretek a bevont ágensekkel - azok sajátvilágával - kapcsolatban elérhetővé válnak a müvekben.

A harmadik dimenzióval kapcsolatos kérdések: Mik annak a közönségnek, nyilvánosságnak a sajátosságai, amelyek számára a mü láthatóvá, megismerhetővé válik? (Mi a mü bemutatásának színtere, és az alkotó kiket kíván megszólítani?) Milyen formában válik megismerhetővé a folyamat és annak eredményei a szélesebb nyilvánosság számára? (Mik a használt médiumok, és milyen cselekvésen keresztül válik elérhetővé a mü a közönség számára?) Milyen problémák mutatkoznak meg a néző számára (számomra)? A müben megismerhető problémák milyen nagyobb társadalmi problémákra irányítják a figyelmemet? Milyen ismereteket szerezhetek a müben szereplő, különböző ágensek sajátvilágáról? A valóság konstruálásának a folyamatában mely ágensek perspektívája válik hangsúlyosabbá, ki(k)nek az értelmezései vállnak hozzáférhetővé számomra?

\section{A három dimenzió a 20 forintos operettben}

\section{A müvész mint résztvevő}

A 20 forintos operettben a projekt megálmodói, kezdeményezői - nevezzük őket most ez esetben müvészeknek - hosszas keresés/válogatás után jutottak el a Tolnai Lajos utcai telekhez, és a mü tervezésekor és megvalósításakor egyaránt erősen építettek a helyi közösségről szerzett tapasztalataikra. A projekt indulása előtt és háromhónapos megvalósítása során naponta több órán keresztül sétáltak az utcákon, beszélgettek és végül dolgoztak a telken, inspirációkat gyüjtve az itt élőktől, a megértés és együttműködés szándékával vezérelve. A társadalomtudományokban alkalmazott résztvevő megfigyelö pozíciójához hasonlatos módon váltak így résztvevővé, vagy mint Hal Foster és Mark Hutchinson gondolatmenetére építve mondhatjuk, művész-antropológussá. ${ }^{5}$

\section{A bevonódás}

A mü aktívan épített a bevonásra, rengeteg embernek adott lehetőséget a részvételre a mü létrehozásában, aki belépett a telekre, egyszerre válhatott nézővé és alkotóvá, egy közösség tagjává.

A szervezők sokféle eszközt bevetettek a résztvevők megszólítására. Hangszerekkel és énekszóval kísérve vidám sétákat tettek a környéken, kiültek hajat vágni a Blaha Lujza térre, hirdették magukat újságban, interneten, plakátokon és nem utolsó sorban a Tolnai Lajos utca 23. számú telek színesre festett kerítésén kihelyezett táblákon. Hangszerek és ruhák készültek a felvonuláshoz, szövegeket és dalokat költöttek, kórus alakult, nőtt a PET-palackokból épített mókus és végül még szőr is nőtt a fején az ingyenes fodrász-szolgáltatásnak köszönhetően. Az operett születésével párhuzamosan pedig a folytatásos szappanopera is formálódott.

5 A müvész mint antropológus szerep gondolata Hall Foster (1996) nyomán terjedt el a müvészetelméletben, de megtaláljuk Suzanne Lacy (1995) egy Fostert megelőző írásában is, illetve Mark Hutchinson Four stages of Public Art (2002) írásában is. 
A munkába több tucat ember (hajléktalanok, szomszédok, gyerekek, helyi aktivisták, turisták, járókelök, fiatal értelmiségiek) kapcsolódott be. Valószínüleg mindenkinek más volt a motivációja, de a projekt befogadó jellege és a szervezők nyitottsága megteremtette azt a légkört, amelyben mindenki otthon érezhette magát. Jelen voltak a szomszédos önkormányzati ház lakói, felnőttek és gyerekek, hoztak tárgyakat a csere-bere piacra, részt vettek a program eseményein, és maguk is kitaláltak új programelemeket. A gyerekek péntekenként elöadást rendeztek a dalokból és a maguk által koreografált táncokból, és ilyenkor sokan mások is kedvet kaptak a szerepléshez. A Tolnai Lajos utcai óvodakert egyszerre vált mühellyé és állandó színpaddá. A résztvevők elmondása alapján sokan nemcsak produkciókat osztottak meg az itt szervezödött közösséggel és közönséggel, hanem életük történeteit is. A bevonódást inspiráló tényezők között gyakran régóta hordozgatott traumák bújtak meg, amelyekre a 20 forintos operett nyitott légköre terápiás hatással bírt. Itt volt, aki meghallgatta az embert, sokan találhattak olyan helyzeteket, feladatokat, amikben hasznosnak érezhették magukat, a gyerekek pedig figyelmet kaptak és nem utolsósorban egy izgalmas vakációt.

\section{A társadalmi részvétel dimenziója}

A mü didaktikus szála - Brecht színházához hasonlóan - minden résztvevőt, aktív és passzív nézőt a társadalom struktúráinak látására, a társadalmi konfliktusok értelmezésére késztetett. Ez a fajta elgondolkodás pedig - egyesek reményei szerint - elősegítheti az aktív társadalmi részvételt, ami a társadalom demokratikus müködésének feltétele.

Amikor ellátogattam a Tolnai Lajos utcába, egy hajléktalan emberjogi aktivistát kértem meg, hogy vezessen körbe: „Kocsis Máté odaadta ezt a telket a hajléktalanoknak. Végül is ő sem gazember, ugyebár. Lehet, hogy jóvá akart tenni valamit. Ez egy ilyen szociális összmüvészeti happening. Mindenki jöhet és alkot, amit szeretne.” - mondta bevezetöként.

No de mit akarhatott jóvátenni a kerület polgármestere? Kétségtelen tény, hogy a projekt pont egy olyan társadalmi csoporttal kereste a kapcsolatot, amelynek helye a kerületben a korábbi években többször is megkérdőjeleződött, és amelynek tagjai sokszor joggal érezhették magukat a helyi politika kereszttüzében. A mü hajléktalan müvészek alkotásaira épült és a megvalósításba is sok hajléktalan kapcsolódhatott be, sőt a történet, amit elmeséltek, sok elemében az ő sorsukat mutatta be. Egy évvel a 20 forintos operett megvalósulása előtt a kerület polgármestere népszavazást írt ki három kérdésben, melynek előzménye néhány önkormányzati rendelet volt (a kukázás megbírságolásáról és a közterületek „életvitelszerű használatáról"), amelyek a hajléktalanok közterületi jelenlétének rendészeti eszközökkel való korlátozását ígérték. A népszavazás érvénytelen lett, és a korábban bevezetett rendeletek is érvényüket veszítették azóta, de a hajléktalanok többségének sorsa közben sem lett jobb.

2012 szeptemberében pedig egy óriás mókus vonult végig azon az útvonalon, ahol tavasszal még transzparensekkel és dobszóval kísérve haladt az „Üres lakások menete”: több tucat hajléktalan és emberjogi aktivista követelte, hogy a kerület segítse a hajléktalanokat és a hajléktalansággal veszélyeztetetteket az üresen álló önkormányzati ingatlanok szociális alapú bérbeadásával.

A napi politika torzító hatásait elkerülendő a projekt gazdái igyekeztek elutasítani a mü direkt összekapcsolását a kerületben zajlott, hajléktalansághoz kötődő diskurzustól. Ugyanakkor sok „néző” számára megmaradt az asszociáció lehetősége. A projektben született szövegek, amelyeket Rejtő Gábor, Leé József, Orbán Anna és HoCsi alkottak, nem voltak mentesek a politikai utalásoktól és a hajléktalanokat érő megaláztatások bemutatásától.

Ha egy közösség mindennapi élete kerül terítékre egy müvön keresztül, illetve az általa keltett diskurzusban, elkerülhetetlenül megjelenik a politikum dimenziója. Nem feltétlenül az aktuálpolitika, pártpolitika szintjén, hanem a közösség érdekeinek és értékeinek közvetítése 
által, még akkor is, ha az alkotók direkt módon nem kívánnak politikai célokat elérni. A müvészet nem létezik közönség nélkül, és a társadalmi nyilvánosság eseményeinek különbözö színterein jelenik meg, amelyek lehetnek kizárólag a művészet számára fenntartva vagy lehetnek attól akár szinte teljesen távoliak, de mindenképpen a közösségi élet és ezáltal a közélet terei. Így minden, ami ebben a térben felvetődik, közéletivé és ezáltal a szó eredeti értelmében politikaivá válhat.

\section{Lezárás}

A csoport 2012 óta folyamatosan dolgozik Józsefváros közterein és alternatív müvészeti tereiben. Munkájukkal játékos és gyakran provokatív módon világítanak rá a helyi társadalmi és politikai elit kirekesztő gyakorlataira. 2014-ben az önkormányzati választások során Mókus Maxival mint alternatív jelölttel kampányoltak a kerület polgármesteri pozíciójáért, ami lehetőséget teremtett a hivatalos pártjelöltek mellett a köztereken megjelenő szegények problémáinak, az önkormányzati bérlakásokban lakók rossz lakhatási körülményeinek tematizálására. 2016-ban az Utcacsatorna címü projektben szintén hasonló témákat dolgoztak fel egy köztéren felállított TV-stúdió adásával és az azt követő köztéri vetítésekkel. ${ }^{6}$ Megdöbbentő és egyben humoros performanszaikon keresztül sikeresek abban, hogy Józsefváros különböző hátterü, eltérő iskolai végzettségü lakói között közvetítsenek és felhívják a figyelmet a szegények és kirekesztettek helyzetére. A köztéri akcióik révén humorral veszik rá az embereket, hogy megálljnak egy percre, megértsék a mellettük lévők problémáit, megismerjék saját helyüket a sokak számára elnyomást okozó gazdasági és társadalmi rendszerben, és megérezzék a szolidaritás és az egymás iránti kölcsönös kiállás szükségességét. A Pneuma Szöv. tevékenysége nemcsak egy figyelemfelhívó alkotás létrehozását jelenti, hanem a szolidaritás hálózatát hozza létre és jeleníti meg, teszi élővé.

\section{IRODALOM}

Bishop, Claire (2006szerk.) Participation. Whitechapel, London - The MIT Press, Cambridge, Massachusetts.

Brecht, Bertolt (1969) Az elidegenítő effektust teremtő színművészet új technikájának rövid leírása. In: Bertolt Brecht (1969) Színházi tanulmányok. Budapest, Magvető. 163-164. http://www.literatura.hu/szinhaz/elidegenito.htm

Foster, Hall (1996) The Artist as Ethnographer. In: Foster, Hall (1996ed.) The Return of the Real: The Avant-Garde at the End of the Century. The MIT Press, Cambridge, Massachusetts.

Goffman, Erving (2000) Az én bemutatása a mindennapi életben. (ford. Berényi Gábor). Budapest, Pólya - Thalassa Alapítvány.

Habermas, Jürgen (1986) A kommunikatív cselekvés elmélete I-II. Budapest, A Filozófiai Figyelő és a Szociológiai Figyelő külön kiadványa.

Horányi Özséb (2005) Fejezetek az ágens fogalomtörténetéből. In: Társadalmi térben. BME Szociológiai és Kommunikációs tanszék.

${ }^{6}$ Az Utcacsatorna adásai itt nézhetőek meg:

https://www.youtube.com/watch?v=IZz--UlbpE8\&list=PLK5BwDOiO9doguUPNwWqMLH0bGsSLgrNH 
Horányi Özséb (2007szerk.) A kommunikáció, mint participáció. Budapest, Typotex - ORTTAKTI.

Hutchinson, Mark (2002) Four Stages of Public Art. Third Text Vol 16/4: 429-38. https://doi.org/10.1080/0952882031000077666

Kester G. H. (2004) Conversation Pieces. University of California Press, Berkeley - Los Angeles - London.

Lacy, Suzanne (1994) Debated territory. Towards a Critical Language for Public Art. In: Lacy, Suzanne (1994ed.) Mapping the Terrain. New Genre Public Art. Bay Press, Seattle, Washington. 171-185.

Vörös Miklós - Frida Balázs (2006) Az antropológiai résztvevő megfigyelés története. In: Letenyei László (2006szerk.) Településkutatás II. Módszertani kézikönyv és szöveggyüjtemény. 395-416. 